\title{
Introduction
}

The first United Nations Conference on the Human Environment opened on 6 June 1972. The meeting was held in Stockholm and brought together politicians, researchers, and environmental activists from all over the world. The discussions continued for two weeks and were based on a growing realization that humanity was threatened. Humans themselves were on the verge of destroying their own living environment. Prior to the conference, the report Only One Earth: The Care and Maintenance of a Small Planet $(1972)^{1}$ was compiled. The front cover featured a picture of the Earth from space. It was a place of life surrounded by a pitch-black void. Humanity's future was at stake.

To the inhabitants of Sweden in 1972, the threat to the planet and to humanity was nothing new. Anyone who regularly read newspapers, listened to the radio, or watched the television news would have encountered the global environmental crisis. School pupils had participated in educational days and watched documentary films. A myriad of small environmental organizations had been founded throughout the country. Intensive debates were being held within and between the five parties in the Swedish parliament, the Riksdag. The European Year of Nature Conservation had been celebrated in 1970, and a year later the concept of the 'Green Movement' (literally 'the Green Wave', gröna vågen in Swedish) had been coined. So knowledge about an environmental crisis was definitely circulating in Swedish society in the early 1970s.

Five years earlier, in the summer of 1967, things were different. At that time it was not self-evident that humans were in the process of destroying their own living environment. Of course, many people had noticed the debate about biocides in agriculture and had heard

1 Barbara Ward and René Dubos, Only One Earth: The Care and Maintenance of a Small Planet (London: Deutsch, 1972). 
about the dangers of mercury. Some had even read Rachel Carson's Silent Spring (1962). However, in the mid-1960s hardly anyone, even among scientists and politicians, thought in terms of humanity standing on the brink of a global environmental crisis. The various environmental hazards were mainly viewed as separate problems. Each field had its own experts, laws, and technologies. The global systems thinking that characterized the Stockholm Conference in 1972 was not generally prevalent in the summer of 1967 . In the next five years a major change occurred in Sweden, as also happened in large parts of the world. ${ }^{2}$

This book explores the major social breakthrough of environmental issues in Sweden. What was it that opened people's eyes to the environmental crisis? When did it happen? Who set the ball rolling? What was done to make it happen? Indeed, what actually happens when knowledge of a kind that has only engaged small groups of people for a long time begins to be noticed in the lives of the vast majority? What happens to society? And what happens to the knowledge?

These issues and themes intersect with our own time. What happened in the years around 1970 was not an isolated chain of events. It had repercussions. To contemporary readers, some of the statements and images I write about will feel strangely familiar.

2 John McCormick, Reclaiming Paradise: The Global Environmental Movement (London: Belhaven Press, 1989); Ramachandra Guha, Environmentalism: A Global History (New York: Longman, 2000); Michael Bess, The Light-Green Society: Ecology and Technological Modernity in France, 1960-2000 (Chicago, IL: University of Chicago Press, 2003); Kai F. Hünemörder, Die Frühgeschichte der globalen Umweltkrise und die Formierung der deutschen Umweltpolitik (1950-1973) (Stuttgart: Steiner, 2004); Jens Ivo Engels, Naturpolitik in der Bundesrepublik: Ideenwelt und politische Verhaltensstile in Naturschutz und Umweltbewegung 1950-1980 (Paderborn: Schöningh, 2006); Michael Egan, Barry Commoner and the Science of Survival: The Remaking of American Environmentalism (Cambridge, MA: MIT Press, 2007); Frank Uekötter, The Greenest Nation?: A New History of German Environmentalism (Cambridge, MA: MIT Press, 2014); Adam Rome, The Genius of Earth Day: How a 1970 Teach-in Unexpectedly Made the First Green Generation (New York: Hill and Wang, 2013); Joachim Radkau, The Age of Ecology (Cambridge: Polity Press, 2014); Sabine Höhler, Spaceship Earth in the Environmental Age, 1960-1990 (London: Pickering \& Chatto, 2015); Perrin Selcer, The Postwar Origins of the Global Environment: How the United Nations Built Spaceship Earth (New York: Columbia University Press, 2018); Paul Warde, Libby Robin, and Sverker Sörlin, The Environment: A History of the Idea (Baltimore, MD: Johns Hopkins University Press, 2018). 
Many of them could have been taken from our own time. The similarities between now and then call for reflection and contemplation. Above all, though, this book aims to provide new historical insights - new because the breakthrough of environmental issues in Sweden in the late 1960s is not a particularly well-known historical process, especially not outside the nation's borders.

What happened in Swedish society was, however, remarkable even from a global perspective. First, the breakthrough of environmental issues in Sweden occurred strikingly early. As early as the autumn of 1967, about a dozen Swedish scientists publicly warned of a global environmental crisis. The researchers had strong ties to the government, the armed forces, and influential media. Unique conditions for moving from knowledge to action existed in Sweden. Second, there was a direct link between the breakthrough of environmental issues in Sweden in the autumn of 1967 and the Stockholm Conference of 1972. The first steps towards the latter were taken on 13 December 1967, when the Swedish UN delegation proposed that a major international environmental conference should be held in the early 1970s. The diplomats acted independently, knowing that people back home were deeply committed to environmental issues. ${ }^{3}$

It may seem surprising that the breakthrough of environmental issues in Sweden has not previously been studied in depth. Given the topicality of environmental and climate issues today, surely masses of historians and social scientists should have traced their roots? Perhaps, though, it is precisely because environmental awareness is so self-evident today that we do not consider that it also has a history. In addition, environmental involvement tends to focus on the present and the future. For people who want to contribute to sustainable social development, the past is not an obvious starting point, especially not the recent past. As a rule, geological and evolutionary time spans overshadow the postwar period.

Nor is the breakthrough of environmental issues a particularly well-known process among people interested in modern history. This is not because the late 1960s have been forgotten by researchers.

3 Lars-Göran Engfeldt, From Stockholm to Johannesburg and Beyond: The Evolution of the International System for Sustainable Development Governance and its Implications (Stockholm: Government Offices of Sweden, Ministry of Foreign Affairs, 2009), p. 32; Erik Paglia, 'The Swedish Initiative and the 1972 Stockholm Conference: The Decisive Role of Science Diplomacy in the Emergence of Global Environmental Governance', Humanities and Social Sciences Communications 8.2 (2021), 1-10. 
On the contrary, few postwar periods have been studied so intensely. This interest, however, has primarily been focused on left-wing radicalization and the legendary year 1968 . In that time and place, environmental issues were not the centre of attention. It was not until the 1970s, with the Stockholm Conference, the Club of Rome's report on the limits to growth, and the organized resistance to nuclear power, that environmental issues became trendsetting. Or was it? True, from the student left's perspective, that was perhaps the case. But Swedish society was significantly larger than the student left. $^{4}$

A similar argument can be made about the environmental crisis. It was not only of concern to people who were involved in new social movements. In fact, the big breakthrough in Sweden happened before any environmental or alternative movement existed at all. In this book I will argue that the decisive turning point occurred in the autumn of 1967 . The driving actors in this process were all part of the social establishment. They were researchers, politicians, editors, and journalists at the major daily newspapers. They had powerful positions and institutional resources. The more small-scale grassroots activism only came later. In the neighbouring countries of Denmark, Norway, and Finland, the breakthrough did not happen until a couple of years later and therefore evolved a different social and political dynamic. ${ }^{5}$

4 Kim Salomon, Rebeller i takt med tiden: FNL-rörelsen och 60-talets politiska ritualer (Stockholm: Rabén Prisma, 1996); Kjell Östberg, 1968 - när allting var $i$ rörelse: Sextiotalsradikaliseringen och de sociala rörelserna (Stockholm: Prisma, 2002); Kjell Östberg and Jenny Andersson, Sveriges historia: 1965-2012 (Stockholm: Norstedts, 2013); Thomas Ekman Jørgensen, Transformation and Crises: The Left and the Nation in Denmark and Sweden, 1956-1980 (New York: Berghahn, 2008); Henrik Berggren, 68 (Stockholm: Max Ström, 2018).

5 Andrew Jamison, Ron Eyerman, and Jacqueline Cramer with Jeppe Læssøe, The Making of the New Environmental Consciousness: A Comparative Study of the Environmental Movements in Sweden, Denmark and the Netherlands (Edinburgh: Edinburgh University Press, 1990); Andrew Jamison and Erik Baark, 'National Shades of Green: Comparing the Swedish and Danish Styles in Ecological Modernisation', Environmental Values 8.2 (1999); Peder Anker, 'Den store økologiske vekkelsen som har hjemsøkt vårt land', in John Peter Collett (ed.), Universitetet $i$ Oslo: 1811-2011 (Oslo: Unipub, 2011); Bredo Berntsen, Grønne linjer: Natur- og miljøvernets historie i Norge (Oslo: Unipub, 2011); Tuomas Räsänen, 'Converging Environmental Knowledge: Re-evaluating the Birth of Modern Environmentalism in Finland', Environment and History 18.2 (2012); David Larsson Heidenblad, 'En nordisk blick 
I have chosen to characterize what happened in Sweden in the autumn of 1967 as a social breakthrough of knowledge. By this I mean a historical process whereby a form of knowledge starts to become very important to many people. The breakthrough of environmental issues is almost an archetypal example of such a historical process. The knowledge which then began to circulate was not new, neither in form nor in content. Nor was it based on any new scientific findings or insights. From the perspective of the history of ideas and of science, it is instead the late 1940s which is the critical turning point. That was when the understanding about a threatened world and humanity was carved out among small - but influential and well-resourced - elite circles at the global level. ${ }^{6}$ For most people, this development was out of sight and irrelevant. It would take almost two decades before the looming environmental crisis became part of the lives of the vast majority. For this reason I have chosen to begin my investigation in the autumn of 1967.

\section{The history and circulation of knowledge}

My study of the breakthrough of environmental issues seizes on and seeks to develop the new research field concerned with the history of knowledge. This field has emerged during the 2000s and brings together researchers from various historical specialities. In the early 2000s, the discussions were mainly conducted in Germanspeaking Europe around the concept of Wissensgeschichte. ${ }^{7}$ Around 2015, however, international interest began to grow, not

på det moderna miljömedvetandets genombrott', in Erik Bodensten, Kajsa Brilkman, David Larsson Heidenblad, and Hanne Sanders (eds), Nordens historiker: En vänbok till Harald Gustafsson (Lund: Mediatryck, 2018); Peder Anker, The Power of the Periphery: How Norway Became an Environmental Pioneer for the World (Cambridge: Cambridge University Press, 2020); Hallvard Notaker, 'Staging Discord: Nordic Corporatism in the European Conservation Year 1970', Contemporary European History 29.3 (2020).

6 Warde, Robin, and Sörlin, The Environment.

7 Ulrich Johannes Schneider, 'Wissensgeschichte, nicht Wissenschaftsgeschichte', in Axel Honneth and Martin Saar (eds), Michel Foucault: Zwischenbilanz einer Rezeption (Frankfurt am Main: Suhrkamp, 2003); Jakob Vogel, 'Von der Wissenschafts- zur Wissensgeschichte der "Wissensgesellschaft", Geschichte und Gesellschaft 30 (2004); Philipp Sarasin, 'Was ist Wissensgeschichte?', Internationales Archiv für Sozialgeschichte der deutschen Literatur (IASL) 36 (2011); Daniel Speich Chassé and David Gugerli, 'Wissensgeschichte: Eine Standortbestimmung', Traverse: Zeitschrift 
least in the Nordic countries. At that time Johan Östling launched the equivalent Swedish term, 'kunskapshistoria', and the following year Peter Burke published What is the History of Knowledge? (2016). ${ }^{8}$ Since then the international discussion has continued to grow and a number of networks, international journals, and major research projects have been initiated. ${ }^{9}$

However, the rapid growth of the field, as well as its broadly inclusive label, has led to a debate over its value. Critics argue that the history of knowledge is vaguely defined and seems mostly to

für Geschichte 19.1 (2012); Jürgen Renn, 'From the History of Science to the History of Knowledge - and Back', Centaurus: An International Journal of the History of Science \& its Cultural Aspects 57.1 (2015).

8 Johan Östling, 'Vad är kunskapshistoria?', Historisk tidskrift 135.1 (2015); Peter Burke, What is the History of Knowledge? (Cambridge: Polity Press, 2016).

9 For an overview see Johan Östling, David Larsson Heidenblad, Erling Sandmo, Anna Nilsson Hammar, and Kari H. Nordberg, 'The History of Knowledge and the Circulation of Knowledge: An Introduction', in Johan Östling, Erling Sandmo, David Larsson Heidenblad, Anna Nilsson Hammar, and Kari H. Nordberg (eds), Circulation of Knowledge: Explorations in the History of Knowledge (Lund: Nordic Academic Press, 2018); Martin Mulsow and Lorraine Daston, 'History of Knowledge', in Marek Tamm and Peter Burke (eds), Debating New Approaches to History (London: Bloomsbury Academic, 2019); Sven Dupré and Geert Somsen, 'The History of Knowledge and the Future of Knowledge Societies', Berichte zur Wissenschaftsgeschichte 42.2-3 (2019); Maria Simonsen and Laura Skouvig, 'Videnshistorie: Nye veje i historievidenskaberne', Temp - Tidskrift for historie 10.19 (2020); Johan Östling, David Larsson Heidenblad, and Anna Nilsson Hammar, 'Developing the History of Knowledge', in Johan Östling, David Larsson Heidenblad, and Anna Nilsson Hammar (eds), Forms of Knowledge: Developing the History of Knowledge (Lund: Nordic Academic Press, 2020); Johan Östling and David Larsson Heidenblad, 'Fulfilling the Promise of the History of Knowledge: Key Approaches for the 2020s', Journal for the History of Knowledge 1.1 (2020). Two new book series were launched in 2019: Routledge's 'Knowledge Societies in History' (edited by Sven Dupré and Wijnand Mijnhardt) and Rowman \& Littlefield International's 'Global Epistemics' (edited by Inanna Hamati-Ataya). KNOW: A Journal on the Formation of Knowledge, whose first issue was published in 2017, has Shadi Bartsch-Zimmer as its editor-in-chief and is the main journal of the Stevanovich Institute on the Formation of Knowledge, University of Chicago. The Journal for the History of Knowledge (editors-in-chief: Sven Dupré and Geert Somsen) published its first issue in 2020. In addition, a number of journals devote special issues or theme sections to the history of knowledge, including Geschichte und Gesellschaft, History and Theory, History of Humanities, Slagmark, and Tidskrift for Kulturstudier. 
be a new name for something that researchers have long been working on. These objections have been raised in particular by historians of ideas and science. ${ }^{10}$ My own position is that it is a little too early to rule on what original and viable contributions the field does or does not make. Historical scholarship is a slow activity, and it takes a number of years before intellectual ambitions are manifested in pioneering research. I do, however, believe that historians of knowledge should take the objections to the field very seriously. During the 2020s, representatives of the field need to be able to show how their approaches differ from those of others. Their answers both can and should be nuanced and numerous. The history of knowledge is not a theoretical school of thought but rather an integrative field. It is broad enough to accommodate various lines of inquiry and conflicting voices. ${ }^{11}$

My own understanding of the history of knowledge and its potential stems from the perspective of cultural and social history. For me, the focus lies on the social relevance and scope of knowledge. This form of the history of knowledge centres on things that many people have perceived as knowledge, treated as knowledge, and based their actions on as knowledge. By studying this type of phenomenon, I want to contribute to the writing of a broader social history in which knowledge is as self-evident a starting point as politics, economics, or gender. That is not the case today. The lack of interest in knowledge contributes to the fact that even historical processes with far-reaching consequences and obvious contemporary relevance - such as the breakthrough of environmental issues - tend to be marginalized in broader forms of historical writing. The history of knowledge is needed in order to change this oversight.

A key concept in the history of knowledge is circulation. With this, the focus is on how knowledge is shaped and reshaped when it is in motion. The theoretical starting point is that knowledge does

10 Lorraine Daston, 'The History of Science and the History of Knowledge', KNOW: A Journal on the Formation of Knowledge 1.1 (2017); Suzanne Marchand, 'How Much Knowledge is Worth Knowing? An American Intellectual Historian's Thoughts on the Geschichte des Wissens', Berichte zur Wissenschaftsgeschichte 42.2-3 (2019); Staffan Bergwik and Linn Holmberg, 'Standing on Whose Shoulders? A Critical Comment on the History of Knowledge', in Östling, Larsson Heidenblad, and Nilsson Hammar (eds), Forms of Knowledge.

11 See Östling, Larsson Heidenblad, and Nilsson Hammar (eds), Forms of Knowledge. 
not exist in any 'pure' form. Knowledge requires channels and bearers in order to move and operate. ${ }^{12}$ Johan Östling, with whom I have worked closely to develop a Nordic-based history of knowledge, explains this by saying that knowledge is always formatted..$^{13}$ That said, knowledge exists in a constant state of potential change, and mapping and analysing knowledge in motion hence becomes a central research task. ${ }^{14}$

The concept of circulation is currently used in many different ways by researchers both within and outside the history of knowledge field. Its power seems to lie in its ability to offer a concrete alternative to linear dissemination models, which many people reject on theoretical grounds. The concept of circulation thereby complicates questions about how knowledge is produced and becomes important. ${ }^{15}$ The most radical voices even question the principle of dissemination and the existence of some kind of starting point for knowledge. From this perspective, production and circulation are inseparable. ${ }^{16}$

I myself, as should be clear by now, am primarily interested in how knowledge moves on a social level. That is, how something

12 Philipp Sarasin and Andres Kilcher, 'Editorial', Nach Feierabend: Zürcher Jahrbuch für Wissensgeschichte 7 (2011), 8.

13 Östling, 'Vad är kunskapshistoria?', 112.

14 James Secord, 'Knowledge in Transit', Isis 95.4 (2004); Anders Ekström, 'Vetenskaperna, medierna, publikerna', in Anders Ekström (ed.), Den mediala vetenskapen (Nora: Nya Doxa, 2004); Andreas Daum, 'Varieties of Popular Science and the Transformation of Public Knowledge', Isis 100.2 (2009); Solveig Jülich, 'Lennart Nilsson's A Child is Born: The Many Lives of a Best-selling Pregnancy Advice Book', Culture Unbound: Journal of Current Cultural Research 7.4 (2015).

15 Claude Markovits, Jacques Pouchepadass, and Sanjay Subrahmanyam (eds), Society and Circulation: Mobile People and Itinerant Cultures in South Asia, 1750-1950 (London: Anthem, 2006); Kapil Raj, Relocating Modern Science: Circulation and the Construction of Knowledge in South Asia and Europe, 1650-1900 (Basingstoke: Palgrave MacMillan, 2007); Lissa Roberts (ed.), Local Encounters and Global Circulation, special issue of Itinerario 33.1 (2009); Mary Terrall and Kapil Raj (eds), Circulation and Locality in Early Modern Science, special issue of British Journal for the History of Science 43.4 (2010); Bernard Lightman, Gordon McOuat and Larry Stewart (eds), The Circulation of Knowledge Between Britain, India, and China: The Early-Modern World to the Twentieth Century (Leiden: Brill, 2013); Johan Östling, Erling Sandmo, David Larsson Heidenblad, Anna Nilsson Hammar, and Kari H. Nordberg (eds), Circulation of Knowledge.

16 Sarasin and Kilcher, 'Editorial'. 
goes from being a matter of concern to some people to becoming of concern to many. Together with Johan Östling, I have chosen to label this understanding of the concept of circulation 'the social circulation of knowledge'. We argue that this more precise definition paves the way for historical studies of key social phenomena which have received far too little attention by scholars. We believe that this concept can contribute to a shift in the centre of gravity - away from a focus on the production and origin of knowledge and towards studies of its circulation and effects. ${ }^{17}$

This view of the history of knowledge does not constitute a radical break with established research traditions. There is great interest in studying publics, media, and public actors, not least within current sociologically inspired research into the history of science. ${ }^{18}$ Despite this, comprehensive studies of social breakthroughs of knowledge are unusual, especially in the subject of history, the discipline in which I myself operate and was trained. It is far more common for historians to study discourses and contexts. Textual interpretations and links to the history of ideas are widespread. Whether or not anyone contemporary with the analysed texts even read and cared about them seems to play less of a role. They are perceived as being interesting in and of themselves. It is, of course, possible to believe this. There are good arguments for studying the unnoticed or the unusual. The risk, though, is that an overly strong focus on socially marginal phenomena will cause broader social

17 Johan Östling and David Larsson Heidenblad, 'Cirkulation - ett kunskapshistoriskt nyckelbegrepp', Historisk tidskrift 137.2 (2017), 279-284; Östling and Larsson Heidenblad, 'Fulfilling the Promise'.

18 Anders Ekström (ed.), Den mediala vetenskapen (Nora: Nya Doxa, 2004); Peter Broks, Understanding Popular Science (Maidenhead: Open University Press, 2006); Johan Kärnfelt, Allt mellan himmel och jord: Om Knut Lundmark, astronomin och den publika kunskapsbildningen (Lund: Nordic Academic Press, 2009); Jonathan Topham, 'Rethinking the History of Science Popularization/Popular Science', in Faidra Papanelopolou, Agustí NietoGalan, and Enrique Perdiguero (eds), Popularizing Science and Technology in the European Periphery 1800-2000 (Farnham: Ashgate, 2009); Agustí Nieto-Galan, Science in the Public Sphere: A History of Lay Knowledge and Expertise (Abingdon: Routledge, 2016); Johan Kärnfelt, Karl Grandin, and Solveig Jülich (eds), Kunskap i rörelse: Kungl. Vetenskapsakademien och skapandet av det moderna sambället (Gothenburg: Makadam, 2018), pp. 377-438; Solveig Jülich, 'Fosterexperimentets produktiva hemlighet: Medicinsk forskning och vita lögner i 1960- och 1970-talets Sverige', Lychnos (2018). 
processes to be obscured. I believe that historians should have the ambition to say something about these processes. For this reason we need to devote more care to what we choose to study in detail. The lives and realities of the vast majority deserve more attention.

As is apparent, my understanding of the history of knowledge and circulation is closely intertwined with my interest in the breakthrough of environmental issues. In fact, my theoretical understanding and my empirical research have shaped each other. I began investigating the breakthrough of environmental issues at the same time as I became involved in the history-of-knowledge field, in the autumn of 2014. Since then, my empirical studies and the more general theoretical and methodological discussions have cross-fertilized one another.

Fundamentally, however, I am an empirically orientated and question-driven researcher who wants to find out new things about various developments in the past. The theoretical and methodological approaches which inspire me are the ones that help me move from curiosity to research. For me, both the formation of the historyof-knowledge field and the concept of circulation have fulfilled such functions. Above all, the discussions have driven me to become more concrete and to place more emphasis on analysing actors, networks, types of media, and chronological sequencing. I would go so far as to say that the study of the social circulation of knowledge requires historical research of a relatively high resolution. At an overly aggregated level, the phenomena that I have found to be most important for social circulation processes are not visible: human actions, interactions, media conditions, and historical processes.

\section{The history of knowledge - a methodological intervention}

My own move into the history of knowledge has brought me closer to a number of fields and research traditions with which generalist historians are not usually in close contact. These include the sociological history of science, intellectual history, the sociology of knowledge, science and technology studies, and the history of the media, books, and education. In Sweden, a number of these fields are gathered under an umbrella discipline called 'the history of science and ideas'. This is an internationally unusual subject framework which, in addition to Sweden, only exists at a few Norwegian and Danish universities. The discipline partly overlaps with the 
history of science and intellectual history, but its nature is broader and more eclectic. ${ }^{19}$

Researchers in the above-mentioned fields have long been interested in knowledge. Scientific worlds and practitioners have been a central focus, but they have in no way been studied in isolation from their surrounding society. On the contrary, ever since Ludwik Fleck's exploration of scientific 'thought collectives' and 'thought styles' in the 1930s, researchers have sought in various ways to shed light on the close relationships between science, politics, economics, technology, the media, and social movements. ${ }^{20}$ With Sheila Jasanoff's concept of 'co-production', it has been emphasized that knowledge

19 Nils Andersson and Henrik Björck (eds), Idéhistoria i tiden: Perspektiv på ämnets identitet under sjuttiofem år (Stockholm: Symposion, 2008); Ellen Krefting, Espen Schaanning, and Reidar Asgaard (eds), Grep om fortiden: Perspektiver och metoder i idéhistorie (Oslo: Cappelen Damm Akademisk, 2017); Mikkel Thorup, Hvad er idéhistorie? (Aarhus: Slagmark forlag, 2019); Anton Jansson, 'Things are Different Elsewhere: An Intellectual History of Intellectual History in Sweden', Global Intellectual History 6.1 (2021); Anton Jansson and Maria Simonsen, 'Kunskapshistoria, idéhistoria och annan historia: En översikt i skandinaviskt perspektiv', Slagmark 81 (2020).

20 Cf.: Ludwik Fleck, Entstehung und Entwicklung einer wissenschaftlichen Tatsache: Einführung in die Lehre vom Denkstil und Denkkollektiv (Basel: Schwabe, 1935); Thomas S. Kuhn, The Structure of Scientific Revolutions (Chicago, IL: University of Chicago Press, 1962); Donna Harraway, 'Situated Knowledges: The Science Question in Feminism and the Privilege of Partial Perspective', Feminist Studies 14.3 (1988); Robert K. Merton, On Social Structure and Science (Chicago, IL: University of Chicago Press, 1996); Sheila Jasanoff, Gerald E. Markle, James C. Peterson, and Trevor Pinch (eds), Handbook of Science and Technology Studies (Thousand Oaks, CA: SAGE, 1995); Sven Widmalm (ed.), Vetenskapsbärarna: Naturvetenskapen $i$ det svenska sambället 1880-1950 (Hedemora: Gidlunds, 1999); Michel Foucault, The Essential Foucault: Selections from Essential Works of Foucault, 1954-1984 (New York: New Press, 2003); Jan Golinski, Making Natural Knowledge: Constructivism and the History of Science (Chicago, IL: University of Chicago Press, 2005); Robert Fox, 'Fashioning the Discipline: History of Science in the European Intellectual Tradition', Minerva 44.4 (2006); Harry Collins and Robert Evans, Rethinking Expertise (Chicago, IL: University of Chicago Press, 2007); Sven Widmalm (ed.), Vetenskapens sociala strukturer: Siu historiska fallstudier om konflikt, samverkan och makt (Lund: Nordic Academic Press, 2008); Jon Agar, Science in the Twentieth Century and Beyond (Cambridge: Polity, 2012); Lorraine Daston, 'Science, history of', in James D. Wright (ed.) International Encyclopedia of the Social and Behavioral Sciences (Oxford: Elsevier, 2015); Lynn K. Nyhart, 'Historiography of the History of Science', in Bernard Lightman (ed.), A Companion to the History 
and social development exist in an almost symbiotic relationship with each other. This has paved the way for critical analyses of the power relationships in which all knowledge production and circulation are involved. ${ }^{21}$ Questions about how scientific legitimacy is created and maintained have also attracted great interest. Drawing on Thomas Gieryn's scholarship, special emphasis has been placed on the various forms of 'boundary work' that scientific actors employ in order to assert authority and gain influence. This work may entail marking territories and maintaining dividing lines, but also exceeding boundaries and emphasizing the relevance of knowledge in new fields, including political ones. ${ }^{22} \mathrm{~A}$ third important concept is 'network' or 'networking', which in scientific studies includes both people and various material objects. In this case, the focus is not on the boundaries but on the relationships between various actors and things. Researchers such as Bruno Latour analyse how networks enable and legitimize knowledge and can make it move between different contexts. $^{23}$

of Science (Chichester: John Wiley \& Sons, 2016); James Poskett, 'Science in History', Historical Journal 63.2 (2020).

21 Sheila Jasanoff, 'Ordering Knowledge, Ordering Society', in Sheila Jasanoff (ed.), States of Knowledge: The Co-production of Science and Social Order (London: Routledge, 2004); Staffan Bergwik, Michael Godhe, Anders Houltz, and Magnus Rodell (eds), Svensk snillrikhet? Nationella föreställningar om entreprenörer och teknisk begåvning 1800-2000 (Lund: Nordic Academic Press, 2014); Anna Tunlid and Sven Widmalm (eds), Det forskningspolitiska laboratoriet: Förväntningar på vetenskapen 1900-2010 (Lund: Nordic Academic Press, 2016).

22 Thomas Gieryn, Cultural Boundaries of Science: Credibility on the Line (Chicago, IL: University of Chicago Press, 1999); Anna Tunlid, Ärftlighetens gränser: Individer och institutioner i framväxten av den svenska genetiken (Lund: Department of Cultural Sciences, History of Ideas Unit, 2004); Staffan Wennerholm, Framtidsskaparna: Vetenskapens ungdomskultur vid svenska läroverk 1930-1970 (Lund: Arkiv, 2005); Per Wisselgren, 'Vetenskap och/ eller politik? Om gränsteorier och utredningsväsendets vetenskapshistoria', in Bosse Sundin and Maria Göransdotter, Mångsysslare och gränsöverskridare: 13 uppsatser $i$ idéhistoria (Umeå: Umeå University, 2008).

23 Bruno Latour, Science in Action: How to Follow Scientists and Engineers through Society (Cambridge, MA: Harvard University Press, 1987); John Law and John Hassard, Actor Network Theory and After (Oxford: Blackwell, 1999); Nina Wormbs, Vem älskade Tele-X? Konflikter om satelliter $i$ Norden 1974-1989 (Hedemora: Gidlunds, 2003); Sven Widmalm and Hjalmar Fors (eds), Artefakter: Industrin, vetenskapen och de tekniska nätverken (Hedemora: Gidlunds, 2004); Bruno Latour, Reassembling the Social: An Introduction to Actor-Network-Theory (Oxford: Oxford University Press, 2005). 
Against this background, it is perhaps not surprising that the rapid emergence of the history-of-knowledge field has been regarded with misgivings in some camps. What exactly is new? How do history-of-knowledge perspectives relate to established discussions and theory constructions? Upon whose shoulders do historians of knowledge actually stand? Indeed, what new insights can the field contribute ${ }^{24}$ As Suzanne Marchand expressed it, might it not just be a matter of 'old wine in slightly stretched wine skins'? Is a new name really needed for something that so many researchers have already devoted so much time to ${ }^{25}$

I want to argue here that the history of knowledge - in the version that Johan Östling and I have tried to develop - does in fact contribute a new orientation. It involves a methodological intervention which aims to generate new questions and lines of research and, by extension, new insights into various key social processes, for example the emergence of modern environmental awareness. Our focus lies on questions about what happens when various forms of knowledge become matters of social concern and intervene in many people's lives. What makes knowledge circulate through society? How does it happen, and what are the consequences? These questions are in themselves not new. However, they neither are nor have been of primary consideration in the fields discussed above. $^{26}$

Paradoxically, the methodological intervention is a consequence of the fact that the foremost area of interest for the new history of knowledge is not knowledge and its epistemic conditions but rather the broader development of society, of which various forms of knowledge are one important aspect. To quote Simone Lässig, the overall goal of those who examine knowledge in circulation is to gain a 'better understanding of societies'. ${ }^{27}$ This ambition is rooted in a fundamental perspective based on social and cultural history, plus a programmatic interest in processes that intervene in the lives of the vast majority. The aim is to contribute more wide-ranging histories of society which include many different voices and

24 Staffan Bergwik, 'Kunskapshistoria: Nya insikter?', Scandia 84.2 (2018); Bergwik and Holmberg, 'Standing on Whose Shoulders?'

25 Marchand, 'How Much Knowledge'.

26 Secord, 'Knowledge in Transit'.

27 Simone Lässig, 'The History of Knowledge and the Expansion of the Historical Research Agenda', Bulletin of the German Historical Institute 59 (2016), 43. 
perspectives. The history of knowledge is thus an attempt to move research in new directions.

In order to achieve this methodological intervention, the study of 'the social circulation of knowledge' is key. This focus directs our attention at when, how, why, and with what consequences knowledge is updated and makes an impression on many people's lives. Public spheres, media forums, influential organizations, and leading actors obviously play a central role; but it is also important to study other actors, groups, and audiences. How can we study the social circulation of knowledge if we only look at those actors who are in the spotlight? In order to study knowledge empirically as a farreaching social phenomenon, we must look more widely and not become stuck in close-up studies of the most obvious historical actors, organizations, and arenas.

That said, it is important not to neglect influential elites, networks, and institutions. Their activities and significance need to be empirically investigated and assessed. The same applies to questions about how knowledge is set in motion and what happens to it when it starts to circulate widely. In this regard, it must be emphasized that we cannot assume in advance that knowledge is never 'spread' or 'seeps down' from elites to the majority without undergoing fundamental change. This may well be the case, but the circulation concept as employed by the history of knowledge makes it an open empirical question.

This pragmatic approach also applies to my view of the question of what knowledge is, and what knowledge it is that I am actually studying. Here I agree with Jürgen Renn's argument that studies of the history of knowledge should try to find a middle ground between knowledge as pertaining to a category of historical actors and knowledge as a purely analytical category. Both of these extremes cause problems. The former may lead to a radically subjectivist and relativistic position which makes it impossible to compare phenomena across time and space. The latter could become anachronistic, simplistic, and empirically difficult to use in historical studies. Renn's way out of this dilemma is to regard studies of the history of knowledge as explorations of both the past and 'the nature of knowledge itself'. ${ }^{28}$ In order for the potential of the history-of-knowledge field to be fulfilled, however, this search must be clarified and discussed,

28 Jürgen Renn, The Evolution of Knowledge: Rethinking Science for the Anthropocene (Princeton, NJ: Princeton University Press, 2020), p. 11. 
so that a better collective understanding of what knowledge is and has been can be developed. In this respect, as Lorraine Daston and other critics have pointed out, historians of knowledge have things to learn from historians of science. ${ }^{29}$

My own practical entry point into this study has been to investigate publicly expressed claims of knowledge about a looming environmental crisis that have had widespread impact, for example via bestselling books. This has been one way of accessing the social circulation of knowledge. I have focused on mapping and analysing how the books were discussed in their own time rather than on analysing their contents. The future-focused expertise that has been accorded to certain actors has been of particular importance. I have subsequently supplemented this initial empirical starting point by following up various threads, actors, organizations, and relationships. With this approach, it has not been possible to find a straightforward definition of what was perceived and handled as knowledge. At different times and for different actors, the main focus and understanding of knowledge about the environmental crisis looked quite different. This is not to say that no patterns exist. However, these patterns are the result of my examinations and analyses rather than something I knew beforehand. For example, with regard to questions about 'knowledge dissemination' and 'the importance of elite actors', my empirical results have taken me in different directions than I had imagined on the basis of my prior theoretical understanding. I do not regard this as a problem but rather as a sign that the history of knowledge actually does function in a way that can give us new insights. What, then, is the significance of this methodological intervention for research on the breakthrough of environmental issues?

\section{The ecological turn}

In international environmental history research, the late 1960s and early 1970s are referred to as 'the ecological turn' or 'the ecological moment'. ${ }^{30}$ This was when environmental issues seriously began to make their presence felt in politics, culture, and social life around the world. Characteristic of this development was that many scientists, such as Barry Commoner in the United States, Jean Dorst in France,

29 Daston, 'The History of Science'; Bergwik and Holmberg, 'Standing on Whose Shoulders?'

30 Jens Ivo Engels, 'Modern Environmentalism', in Frank Uekötter (ed.), The Turning Points of Environmental History (Pittsburgh, PA: Pittsburgh University 
and Hans Palmstierna in Sweden, began to regard it as their task to intervene directly in the social debate in order to try to steer political development down new paths. It was also at this time that the modern environmental movements began to emerge. International organizations such as Friends of the Earth (1969) and Greenpeace (1971) saw the light of day, at the same time as older nature-conservation organizations such as the Sierra Club (1892) and the Swedish Society for Nature Conservation (1909) began to orientate themselves in new directions. In many countries, authorities with special responsibility for environmental issues were established and the legislation in this field was expanded and strengthened. Steps also began to be taken towards deeper international cooperation and agreements. ${ }^{31}$

When the UN's first environmental conference was held in Stockholm in 1972, the theme was 'one world'. It was a vision that ran counter to the way in which the world was generally perceived and functioned at that time. The Cold War was still going on between East and West, and countries in the so-called Third World were recurring arenas for ideological and military confrontations between the blocs. The road to the Stockholm Conference was also lined with high-level political complications. The reason was that East Germany was not allowed to participate because it was not a member of the UN. Most of the Eastern bloc therefore boycotted the event. The only communist countries present were Yugoslavia, China, and Romania. At the conference itself, however, the focus ended up being on the North-South conflict. The Western world's efforts to deal with environmental degradation and overpopulation were pitted against the developing countries' desire for industrialization and prosperity. ${ }^{32}$ The inaugural speech by Sweden's prime minister, Olof Palme, was also controversial. He highlighted 'the tremendous

Press, 2010), pp. 119-120; Holger Nehring, 'Genealogies of the Ecological Moment: Planning, Complexity and the Emergence of "the Environment" as Politics in West Germany, 1949-1982', in Sverker Sörlin and Paul Warde (eds), Nature's End: History and the Environment (Basingstoke: Palgrave Macmillan, 2009).

31 McCormick, Reclaiming Paradise; Guha, Environmentalism; Frank Zelko, Make it a Green Peace!: The Rise of Countercultural Environmentalism (New York: Oxford University Press, 2013); Radkau, The Age of Ecology; Peter Dauvergine, Historical Dictionary of Environmentalism, 2nd edition (London: Rowman \& Littlefield, 2016; first published in 2009).

32 McCormick, Reclaiming Paradise, pp. 88-105; Engfeldt, From Stockholm to Johannesburg; Anne Egelston, Sustainable Development: A History (Dordrecht: Springer Netherlands, 2013). 
destruction caused by extensive indiscriminate bombing' and 'the large-scale use of bulldozers and herbicides' ${ }^{33}$ Although it was not stated explicitly, there was no doubt that his critical remarks were aimed at US conduct in Vietnam, which at that time was described in terms of an 'ecocide'. Palme's speech was not appreciated in Washington. A spokesperson for the US State Department said that 'deep unease' was felt over the way that the prime minister of the host country had raised this issue, which had nothing to do with the environmental-protection conference. ${ }^{34}$ The UN conference was also sharply criticized by the new environmental movements. They argued that the event was a top-down and inadequate symbolic act. As a result, parallel alternative environmental conferences were organized, such as the radical left-wing People's Forum. ${ }^{35}$

In reality, the Stockholm Conference thus highlighted the many and profound contradictions that characterized 'the one world' in 1972. Knowledge of an ongoing environmental crisis was indeed circulating globally at this time, but it was understood and handled in disparate ways within various power blocs and countries. Of course, this had also been the case before the Stockholm Conference. If we look at years like 1970,1967, or 1963, the differences were at least as great as in 1972. In order to understand and explain the ecological turn, we therefore need studies of how the process developed in various societies with differing conditions, problems, and agendas. This will also make it possible to show what the global influence processes looked like in practice, and to analyse the chain reaction that made environmental issues a global political concern. ${ }^{36}$

From such a perspective, it is apparent that the first and strongest driving forces behind the ecological turn came from the United States. As far back as the late 1940s, scientists such as William Vogt and Fairfield Osborn had already begun to influence the social debate. They warned that overpopulation and looting of the planet's resources could eventually lead to a global civilizational collapse. ${ }^{37}$ The warnings were heeded elsewhere in the West. In Sweden, for

33 Anon., 'USA-kritik mot Palme: Oöverlagt och ensidigt om Vietnam', Svenska Dagbladet (SvD), 7 June 1972.

34 Anon., 'USA-kritik mot Palme'.

35 Egelston, Sustainable Development, p. 69.

36 Radkau, The Age of Ecology, p. 79.

37 Thomas Robertson, The Malthusian Moment: Global Population Growth and the Birth of American Environmentalism (New Brunswick: Rutgers, 2012), pp. 36-60; Radkau, The Age of Ecology, p. 91. 
example, they were picked up by food researcher Georg Borgström, who doggedly spread them in Scandinavia. ${ }^{38}$ The next important American impetus came in the early 1960s with Rachel Carson's Silent Spring (1962). It focused attention on the dangers of chemical pesticides and sparked fierce debates between nature-conservation interests, industry representatives, and government agencies. ${ }^{39}$ Carson's book, however, did not give rise to any grassroots movement, at least not right away. Instead, the birth moment of the American environmental movement was the holding of the first Earth Day on 22 April 1970. An estimated 20 million Americans participated in the event which channelled and strengthened the growing environmental involvement, not least among young school pupils and college students. In the words of environmental historian Adam Rome, Earth Day created 'the first green generation'. ${ }^{40}$

From a global perspective, however, the American celebration of Earth Day was less important. For example, Swedish media did not report on it at all. In the UK and Germany interest seems to have been somewhat greater, but environmental historian Frank Uekötter nevertheless states that Earth Day was 'a purely American event'. ${ }^{41}$ Timewise, though, the event coincided with a similar initiative under the auspices of the Council of Europe. The Council had designated 1970 as the European Conservation Year, and political attempts were made throughout the continent to raise awareness of

38 Björn-Ola Linnér, The World Household: Georg Borgström and the Postwar Population-Resource Crisis (Linköping: Tema University, 1998); Sunniva Engh, 'Georg Borgström and the Population-Food Dilemma: Reception and Consequences in Norwegian Public Debate in the 1950s and 1960s', in Johan Östling, Niklas Olsen, and David Larsson Heidenblad (eds), Histories of Knowledge in Postwar Scandinavia: Actors, Arenas, and Aspirations (Abingdon: Routledge, 2020).

39 Thomas Dunlap, DDT: Scientists, Citizens, and Public Policy (Princeton, NJ: Princeton University Press, 1981); Linda Lear, Rachel Carson: Witness for Nature (New York: Holt, 1997); Gary Kroll, 'The "Silent Springs" of Rachel Carson: Mass media and the origins of modern environmentalism', Public Understanding of Science 10.4 (2001); David Vail, Chemical Lands: Pesticides, Aerial Spraying, and Health in North America's Grasslands since 1945 (Tuscaloosa, AL: University of Alabama Press, 2018).

40 Rome, The Genius of Earth Day; David Larsson Heidenblad, 'Så uppstod den första “gröna generationen”', SvD, 20 April 2020.

41 Thorsten Schulz, Das 'Europäische Naturschutzjahr 1970': Versuch einer europaweiten Umweltkampagne (Berlin: Wissenschaftszentrum für Sozialforschung, 2006), pp. 22-23; Uekötter, The Greenest Nation?, p. 82. 
environmental problems. The results were meagre. The European Conservation Year did not become a catalyst for grassroots involvement in Europe. The environmental movements on this side of the Atlantic emerged in other ways. ${ }^{42}$

The difficulties of coming together around environmental issues at the international level are further illustrated by the Nordic Nature Conservation Day, which was held on 6 September 1970. Sweden, Norway, Denmark, and Finland had collaborated to orchestrate a joint demonstration for the environment. The plan was that hundreds of warning beacon fires would be lit across the Nordic region and culminate in a torchlight procession in Oslo, concluding with fireworks. However, the national committees had quite diverse mandates, compositions, and wishes. For example, the Norwegian one had links to radical forces within the emerging environmental movement, whereas the Swedish one actively distanced itself from them. The Danish and Finnish participation seems to have been lukewarm and characterized by tight budgets. ${ }^{43}$

Nordic Nature Conservation Day thereby reflected the differing paths of development followed by the ecological turn in the Nordic region. In 1970 there existed an environmental policy establishment in Sweden centred around the National Environment Protection Board [Statens Naturvårdsverk, now the Swedish Environmental Protection Agency - translator's note]. The board had been established in June 1967 as the first authority in the world of its kind. Behind the move lay the Social Democratic government, which had ruled Sweden since the 1930s. In Norway and Denmark, the Social Democrats were in opposition at this time. Similar environmental protection authorities would not be established there until 1971 (Denmark) and 1972 (Norway). In Finland it took until 1983. However, it was not only on political and administrative grounds that the countries differed. Even more important was the fact that the Swedish scientific research community was large and resource-rich and became involved in the issues early on. In the wake of the biocide debate, the 1964 government enquiry into natural resources was commissioned to survey the environmental situation in Sweden.

42 Uekötter, The Greenest Nation?, p. 82; Jan-Henrik Meyer, 'From Nature to Environment: International Organizations and Environmental Protection before Stockholm', in Wolfram Kaiser and Jan-Henrik Meyer (eds), International Organizations and Environmental Protection (Oxford: Berghahn, 2017); Notaker, 'Staging Discord'.

43 Notaker, 'Staging Discord'. 
Nothing similar happened in the other Nordic countries. The early Swedish warning voices, such as Georg Borgström and Hans Palmstierna, also came to play important roles in the neighbouring countries. There, too, it was not necessarily established scientists who were the most important actors in the social circulation of knowledge. In Norway the philosopher Arne Naess and the advertising executive Erik Dammann came to play a central role during the 1970s. In Denmark it was the student activists within the environmental movement NOAH (1969) who set the tone. ${ }^{44}$

All in all, this meant that the ecological turn acquired a special dynamic in Sweden. In many ways, the similarities were greater with the United States than with Sweden's neighbours and the rest of Western Europe. One important difference, however, was that the Swedish scientists were significantly closer to the centre of national political power than their American counterparts. Barry Commoner and Paul Ehrlich had neither any parliamentary platform nor access to a grassroots movement. ${ }^{45}$ What consequences did this have? How did the environmental turn in Sweden happen?

To investigate this, the methodological intervention of the history of knowledge is particularly helpful: this approach enables an examination of the process of change from a wide-ranging social perspective which also allows for a focus on the historical actors. My study, however, does not only examine the most obvious actors, the scientific warning voices and the environmental activists. They are certainly included and important; but they do not stand alone. In order to study the social circulation of knowledge, the net must be cast more widely.

\section{Three knowledge actors}

A central point of this book is that historical actors were drivers of and within the breakthrough of environmental issues in Sweden. In

44 Jamison, Eyerman, and Cramer, The Making of the New Environmental Consciousness; Jamison and Baark, 'National Shades of Green'; Anker, 'Den store økologiske vekkelsen’; Berntsen, Grønne linjer; Räsänen, 'Converging Environmental Knowledge'; Simone Müller, 'Corporate Behaviour and Ecological Disaster: Dow Chemical and the Great Lakes Mercury Crisis, 1970-1972', Business History 60.3 (2018); Larsson Heidenblad, 'En nordisk blick'; Anker, The Power of the Periphery.

45 Egan, Barry Commoner and the Science of Survival; Robertson, The Malthusian Moment, pp. 126-151. 
my view, the social breakthrough of knowledge occurred because specific people did specific things at specific times, which triggered chain reactions. I want to make this historical dynamic visible in my presentation. For this reason, I have chosen to highlight three knowledge actors in particular: the chemist Hans Palmstierna, the journalist Barbro Soller, and the historian Birgitta Odén. All three were born in the 1920s and were in the midst of their lives and careers during the years I study. They all contributed to the breakthrough of environmental issues, which in turn led to new directions in their own lives and those of others.

Best known in his day was Hans Palmstierna. He was an associate professor of chemistry, did laboratory work at the Karolinska Institute in Stockholm, and worked at the National Bacteriological Institute. He also wrote regularly for the liberal Dagens Nyheter, Sweden's largest and most prestigious broadsheet. Palmstierna came from an old noble family but held strong socialist convictions and was active in the Social Democratic Party. In the autumn of 1967, he published the polemical book Plundring, svält, förgiftning [Plundering, famine, poisoning]. It came to have a huge impact. Palmstierna became the first truly major environmental debater in Sweden. In early 1968, he left his academic career to start working at the National Environment Protection Board. There he combined his new job with ambitious popular education efforts and political assignments for the Social Democrats. On his death in 1975, it was said that he was the person who 'awakened our awareness' and 'really got the environmental debate going, ${ }^{46}$

Hans Palmstierna is not an unknown historical actor, but his personal archive has not been used before. ${ }^{47}$ It includes a rich collection of letters, diaries, and press clippings, which allow his actions to be studied in detail. The many letters enable me to demonstrate

46 Inger Marie Opperud, 'Hans Palmstierna funnen drunknad', Expressen (Exp), 28 May 1975; Björn Berglund, 'Han väckte vårt medvetande', Dagens Nyheter (DN), 29 May 1975; Bo Melander, 'Palmstierna - väckarklocka i flera viktiga miljöfrågor', Göteborgsposten (GP), 29 May 1975.

47 Jamison, Eyerman, and Cramer, The Making of the New Environmental Consciousness, pp. 20-22; Jonas Anshelm, Socialdemokraterna och miljöfrågan: En studie av framstegstankens paradoxer (Stockholm: Brutus Östling's Symposion, 1995), pp. 16-27; Nikolas Glover, 'Unity Exposed: The Scandinavia Pavilions at the World Exhibitions in 1967 and 1970', in Jonas Harvard and Peter Stadius (eds), Communicating the North: Media Structures and Images in the Making of the Nordic Region (Burlington, VT: Ashgate, 2013), pp. 232-234. 
how knowledge circulated in Swedish society at this time. Palmstierna corresponded not only with scientists, fellow political party members, trade-union representatives, and educational associations, but also with clergy, students, bank managers, journalists, and upper-secondaryschool pupils. My study will also show that Palmstierna's position underwent several changes. In the autumn of 1967, he went from being an obscure scientist to the role of a unifying and exalted expert. In the early 1970s, though, he became a controversial person whom many turned against. Here it becomes possible to highlight how environmental knowledge and expertise about the future came to be transformed when the environmental debate was converted into political actions in the 1970s. ${ }^{48}$

Barbro Soller was a different type of knowledge actor from Hans Palmstierna. She was neither a researcher nor a politician but a journalist. Her texts were not published on the culture and editorial pages (the forums where the press mainly conducted the environmental debate); they were more like news reporting. Hired by Dagens Nybeter in 1964, she developed into Sweden's first environmental journalist in its pages. Her big breakthrough came with the reportage series 'Nya Lort-Sverige' [New filth-Sweden] in the spring of 1968. In the series, she travelled around Sweden to document environmental destruction and littering. The following year, the series was brought out as a reportage book by the publisher who was behind Palmstierna's Plundring, svält, förgiftning.

At that time, Barbro Soller's investigative environmental journalism was something completely new. She has been the object of scholarly interest before; in particular, her transition to the TV medium in the early 1970s has attracted attention. ${ }^{49}$ I will instead study an earlier phase of her journalistic career. This can now be done because the newspaper material has been digitized and is full-text searchable. ${ }^{50}$ I am therefore able to survey her activities and analyse her transition from general reporter to investigative environmental journalist. I

48 Paul Warde and Sverker Sörlin, 'Expertise for the Future: The Emergence of Environmental Prediction c.1920-1970', in Jenny Andersson and Egle Rindzevičiūte (eds), The Struggle for the Long-term in Transnational Science and Politics (New York: Routledge, 2015).

49 Monika Djerf Pierre, Gröna nyheter: Miliöjournalistiken i televisionens nybetssändningar 1961-1994 (Gothenburg: Department of Journalism, Media and Communication, University of Gothenburg, 1996).

50 For a discussion see: David Larsson Heidenblad, 'The Emergence of Environmental Journalism in 1960s Sweden: Methodological Reflection on 
can hence place her within a larger history-of-knowledge context and illuminate that context through her.

Alongside Hans Palmstierna and Barbro Soller, Birgitta Odén may appear to be an atypical example. What does a historian, who became a professor by studying sixteenth-century state finances, have to do with the breakthrough and social circulation of knowledge about environmental issues? Quite a lot, actually. In the spring of 1967, Odén was invited to a meeting at the Swedish National Defence Research Institute (FOA) (now the Swedish Research Agency). The initiator of this meeting was the director-general and head of FOA, Martin Fehrm. He perceived the environmental problems as a security threat and felt that they could not be reduced to a scientific and technical issue. They involved people's actions and political decision-making processes. For that reason, knowledge based on the humanities and social sciences was needed. Odén became the driving force behind the setting up of such research. In parallel with this, she tried to launch an environmental history research group at the history department in Lund, mainly by involving young students. In the summer of 1968 , together with political scientists and economists, she submitted a major research application, but it was never granted.

Birgitta Odén's work shows how the breakthrough of environmental issues changed the life of one individual towards the end of the 1960s. It also indicates how a person in her position could inspire others and establish new directions. Some of the students she involved came to devote their lives to these issues. But her story also indicates the importance of networks and personal connections. Her younger brother was the soil chemist Svante Odén, an associate professor at the Swedish University of Agricultural Sciences in Uppsala. It was he who made the scientific discovery of the environmental hazard that was acid rain and who made the Swedish public aware of it through an article in Dagens Nyheter in the autumn of 1967. At the inaugural meeting at FOA in May 1967, both siblings attended. ${ }^{51}$

Hans Palmstierna, Barbro Soller, and Birgitta Odén are not the only actors I study. Through them I reach others, such as the committed layman Sören Gunnarsson, the young environmental activist

Working with Digitalized Newspapers', in Östling, Olsen, and Larsson Heidenblad (eds), Histories of Knowledge in Postwar Scandinavia.

51 David Larsson Heidenblad, 'Miljöhumaniora på 1960-talet? Birgitta Odéns miljöhistoriska initiativ och skissernas historiografi', Scandia 85.1 (2019). 
Wolter Arnberg, the secondary-school teacher Kerstin Hägg, and the Lund University student Lars J. Lundgren. The reason why I selected Palmstierna, Soller, and Odén is because they are central enough actors - and different enough in their missions - that a picture of Swedish society at that time can emerge through them. As far as I know, they did not know one another particularly well, but they definitely knew of one another. They were connected via people like Svante Odén and forums like Dagens Nybeter. There was also a historical simultaneity. In the autumn of 1967, all three were deeply involved in what came to be the breakthrough of environmental issues. The historical process thus becomes visible through them. That said, we will now turn our gaze to the eventful autumn of 1967 . 